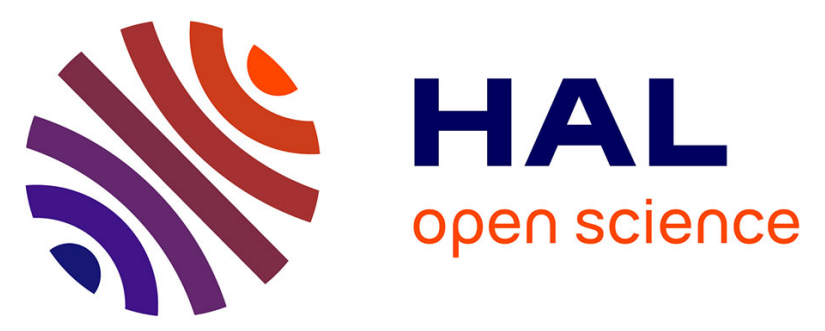

\title{
Zero-Order Versus Intrinsic Kinetics for the Determination of the Time to Maximum Rate under Adiabatic Conditions (TMR ad ): Application to the Decomposition of Hydrogen Peroxide
}

Lamiae Vernières-Hassimi, Amine Dakkoune, Lokmane Abdelouahed, Lionel

Estel, Sébastien Leveneur

\section{To cite this version:}

Lamiae Vernières-Hassimi, Amine Dakkoune, Lokmane Abdelouahed, Lionel Estel, Sébastien Leveneur. Zero-Order Versus Intrinsic Kinetics for the Determination of the Time to Maximum Rate under Adiabatic Conditions (TMR ad ): Application to the Decomposition of Hydrogen Peroxide. Industrial and engineering chemistry research, 2017, 56 (45), pp.13040-13049. 10.1021/acs.iecr.7b01291 . hal-02435634

\section{HAL Id: hal-02435634}

https://hal-normandie-univ.archives-ouvertes.fr/hal-02435634

Submitted on 13 Jan 2022

HAL is a multi-disciplinary open access archive for the deposit and dissemination of scientific research documents, whether they are published or not. The documents may come from teaching and research institutions in France or abroad, or from public or private research centers.
L'archive ouverte pluridisciplinaire HAL, est destinée au dépôt et à la diffusion de documents scientifiques de niveau recherche, publiés ou non, émanant des établissements d'enseignement et de recherche français ou étrangers, des laboratoires publics ou privés. 


\section{Zero-order versus intrinsic kinetics for the determination of $\mathrm{TMR}_{\mathrm{ad}}$ : Application to the decomposition of hydrogen peroxide}

Lamiae Vernières-Hassimi ${ }^{l}$, Amine Dakkoune ${ }^{l}$, Lokmane Abdelouahed ${ }^{l}$, Lionel Estel ${ }^{l}$, Sébastien Leveneur $* 1,2$

${ }^{1}$ Normandie Univ, INSA Rouen, UNIROUEN, LSPC, EA4704, 76000 Rouen, France, E-mail : sebastien.leveneur@insa-rouen.fr

${ }^{2}$ Laboratory of Industrial Chemistry and Reaction Engineering, Johan Gadolin Process

Chemistry Centre, Åbo Akademi University, Biskopsgatan 8, FI-20500 Åbo/Turku, Finland.

KEYWORDS: safety criteria, adiabatic reactor, $\mathrm{TMR}_{\mathrm{ad}}$, zero-order model, kinetic modeling. 
GRAPHICAL ABSTRACT.

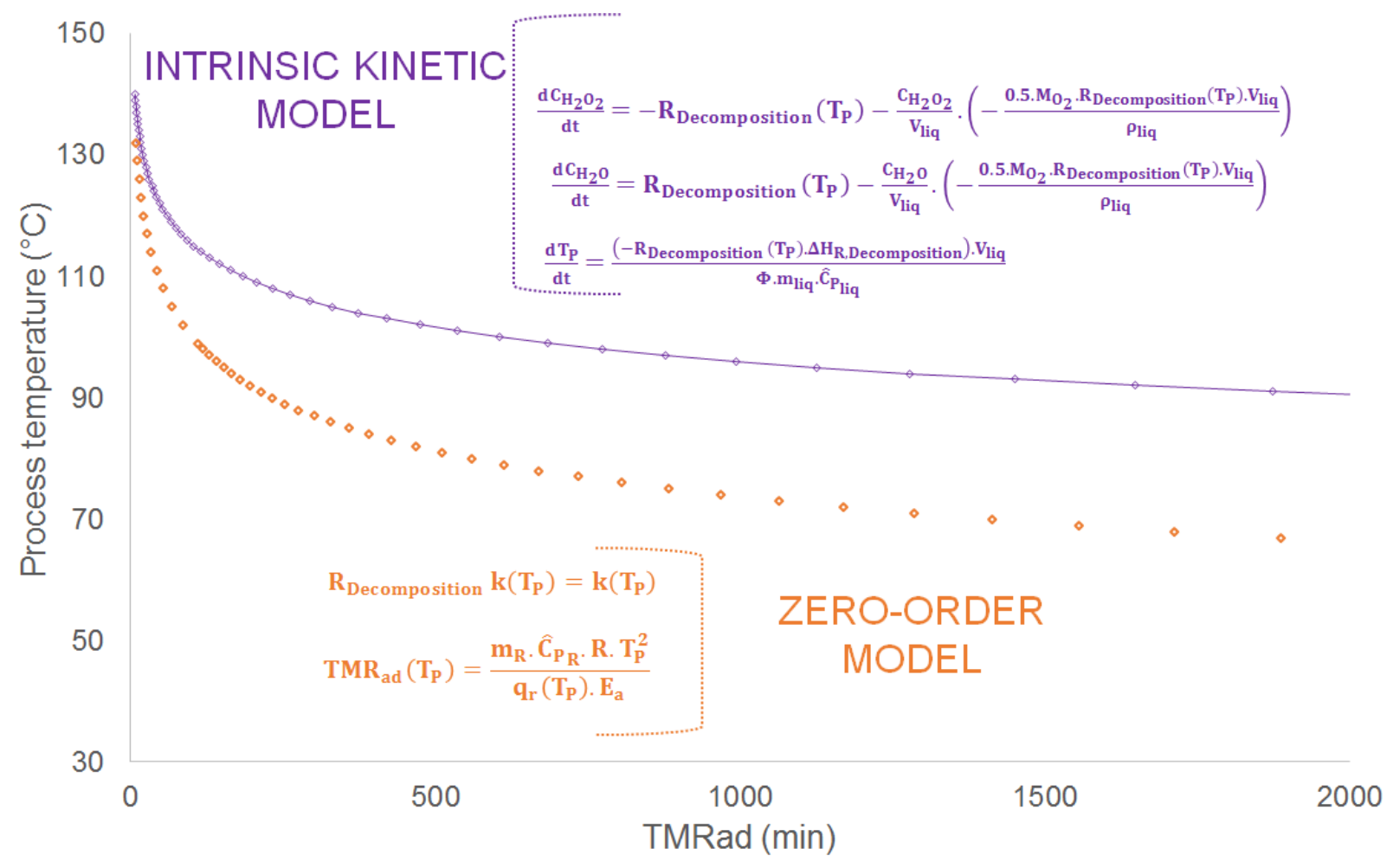




\section{ABSTRACT.}

Thermal safety of chemical processes requires the knowledge of safety parameters quantifying the probability like time-to-maximum rate under adiabatic conditions $\left(\mathrm{TMR}_{\mathrm{ad}}\right)$ and the severity like adiabatic temperature rise under adiabatic conditions $\left(\Delta \mathrm{T}_{\mathrm{ad}}\right)$. The zero-order approximation is used to ease the determination of $\mathrm{TMR}_{\mathrm{ad}}$ values at different process temperature, but how to be sure that this approximation is acceptable compared to the use of an intrinsic kinetic model? In the literature, there are not such studies that compare the values of $\mathrm{TMR}_{\mathrm{ad}}$ by using zero-order and intrinsic kinetic models. For that, decomposition of hydrogen peroxide in the presence and in the absence of copper sulfate was studied in an advanced reactive system screening tool (ARSST) unit. This calorimeter works under near-adiabatic conditions based on heat loss compensation principle and by using a background heating rate $(\beta)$. In a first stage, a kinetic model was built to estimate the intrinsic kinetic constants. Then, a comparison between the values of $\mathrm{TMR}_{\mathrm{ad}}$ from the zero-order and the intrinsic kinetic model was performed. It was found that the difference of $\mathrm{TMR}_{\mathrm{ad}}$ values obtained by these two models can be significant. The influence of $\beta$ and reactant concentrations were found to play an important role on this difference. A good practice in case of kinetic and thermodynamic data missing, a user should test different background heating rates to verify their influence on $\mathrm{TMR}_{\mathrm{ad}}$ values obtained from the zero-order model. 


\section{INTRODUCTION}

Safety assessment of a chemical plant is complex because it requires the knowledge of the different process units, chemicals reactivity and toxicology. ${ }^{1}$ Furthermore, one should define a clear methodology to rank the different risks (toxic, thermal, environmental, etc.). The determination of safety parameters for thermal risk can be cumbersome because the reactivity of the chemical system and reactor characteristic should be known. This risk is important. For example, Balasubramanian and Louvar ${ }^{2}$ have revealed that $26 \%$ of the major petrochemical plant accidents are due to runaway.

Thermal runaway occurs when the heat flow-rate due to chemical reactions is higher than the one removed by the cooling system. Before ranking this risk for an exothermic reaction system, the kinetics and thermodynamics of the reaction system should be characterized at some extent. Saada et al., ${ }^{3}$ have shown that runaway reaction accidents in chemical industries are important due to a non-systematic assessment of chemical hazards.

Several causes can lead to a thermal runaway situation: wrong operating conditions (reactants loading or thermal conditions), malfunction of the cooling system (low heat exchange surface area, failure of the automate system, cooling failure...), presence of exothermic secondary reactions, etc.

${ }^{3}$ In the first stage of this accident, there is a shift from a controlled reaction temperature to an uncontrolled reaction temperature. In the worst-case scenario, the uncontrolled reaction temperature can lead to an adiabatic thermal mode. In the second stage, there is a fast temperature increase due to the exothermic reactions which could trigger secondary reactions, ${ }^{1}$ i.e., decomposition reactions producing non-condensable products. The worst final consequence is the overpressure in the reactor leading to the explosion of the reactor structure. 
Depending on the operating conditions (initial temperature, reactants loading, concentrations, etc.), the consequences vary from loss and disruption of production to the irreversible damage of the unit process and plant worker fatalities. ${ }^{4}$

The main challenges to rank the thermal risk of a chemical process are to determine some safety criteria and to measure some safety parameters. Thermal risk is the product of the probability of occurrence by the severity.

The parameter describing the severity of the thermal risk is the adiabatic temperature rise $\left(\Delta \mathrm{T}_{\mathrm{ad}}\right)$, which represents the temperature increase due to chemical reactions under adiabatic conditions. The severity parameter is linked to the thermodynamic constant: reaction enthalpy. From this parameter, it is possible to distinguish two other severity parameters:

- Maximum temperature for synthesis reactions (MTSR), which is the temperature increase due to the synthesis reactions under adiabatic conditions,

- Final temperature $\left(\mathrm{T}_{\text {final }}\right)$, which is the temperature increase due to the synthesis and secondary reactions under adiabatic conditions.

The parameter describing the probability of the thermal risk is the time-to-maximum rate under adiabatic conditions at a process temperature $\mathrm{T}_{\mathrm{p}}\left(\mathrm{TMR}_{\mathrm{ad}}\left(\mathrm{T}_{\mathrm{p}}\right)\right)$. The probability parameter is linked to the kinetics of the reaction system. For a thermal risk assessment, it is important to determine two particular probability parameters:

- $\mathrm{T}_{\mathrm{D} 24}$ which represents the initial process temperature to reach the maximum reaction rate in 24 hours. Stoessel ${ }^{1}$ defines this temperature as the one at which the thermal stability of the reaction mixture is not a problem. 
- $\mathrm{T}_{\mathrm{D} 8}$ which represents the initial process temperature to reach the maximum reaction rate in 8 hours.

The determination of MTSR can be measured directly by calorimetry ${ }^{5-6}$ or by knowing the reaction enthalpies. ${ }^{7}$ The determination of the final temperature can be difficult because the thermodynamics of secondary reactions could be unknown. The experimental determination of MTSR and $\mathrm{T}_{\text {final }}$ in adiabatic reactors requires that these calorimeters have a low $\Phi$-factor. The $\Phi$ factor represents the thermal inertia of the reactor. As this factor is close to one, the thermal system is close to adiabatic mode and the measurement is reliable. ${ }^{8}$

The safety parameter time-to-maximum rate under adiabatic conditions $\mathrm{TMR}_{\mathrm{ad}}\left(\mathrm{T}_{\mathrm{p}}\right)$ can be measured by calorimetry or by knowing the kinetic and thermodynamic constants. Nevertheless, the detailed kinetic model for a reaction system including synthesis and secondary reactions can be time-consuming and cumbersome. For example, secondary reactions can involve radicals, which are not easy to follow and model. ${ }^{9}$ The experimental determination of $\mathrm{T}_{\mathrm{D} 24}$ can also be cumbersome because it depends on the temperature sensitivity of the calorimeter and its $\Phi$-factor. In case this parameter cannot be directly measured by an adiabatic calorimeter, then the determination of $\mathrm{T}_{\mathrm{D} 24}$ is done by extrapolation. Usually, the zero-order approximation is applied, allowing to determine rapidly the values of $\mathrm{TMR}_{\mathrm{ad}}$ at different process temperatures. ${ }^{5}$ By using this assumption, $\mathrm{TMR}_{\mathrm{ad}}\left(\mathrm{T}_{\mathrm{P}}\right)$ can be expressed as

$\mathrm{TMR}_{\mathrm{ad}}=\frac{\mathrm{m}_{\mathrm{R}} \cdot \widehat{\mathrm{C}}_{\mathrm{P}_{\mathrm{R}}} \cdot \mathrm{R} \cdot \mathrm{T}_{\mathrm{P}}^{2}}{\mathrm{q}_{\mathrm{r}}\left(\mathrm{T}_{\mathrm{p}}\right) \cdot \mathrm{E}_{\mathrm{a}}}$

where $m_{R}$ is the reaction mixture mass, $\widehat{C}_{P_{R}}$ is the specific heat-capacity of the reaction mixture, $R$ is the gas constant, $T_{P}$ is the initial process temperature, $\mathrm{q}_{\mathrm{r}}\left(\mathrm{T}_{\mathrm{P}}\right)$ is the heat-flow rate due to chemical 
reactions and $E_{a}$ is the apparent activation energy. The use of this approximation to determine the probability parameters can be found in Supporting Information and in the articles of our group. ${ }^{5,10}$

The safety community uses the zero-order approximation because it gives rapidly the safety parameters $\left(\mathrm{TMR}_{\mathrm{ad}}\right)$ in the worst-case conditions. Nevertheless, this method does not consider the concentrations of any compounds. Hence, the TMR ad values obtained by this method are correct for specific operating conditions. How is reliable the determination of $\mathrm{TMR}_{\mathrm{ad}}\left(\mathrm{T}_{\mathrm{p}}\right)$ or $\mathrm{T}_{\mathrm{D} 24}$ and $\mathrm{T}_{\mathrm{D} 8}$ by using this approximation? To the best of our knowledge, there are no studies that compare the probability parameters obtained from the intrinsic kinetic model and the zero-order kinetic model. The goal of this manuscript is to fill this gap by studying the decomposition of hydrogen peroxide.

Several articles describe the peroxide stability or decomposition by calorimeters due to the high reactivity of the chemical bond O-O. The study of peroxide compounds decomposition as test system for calorimeter is frequent.${ }^{11}$ For instance, the oxidation of sodium thiosulfate by hydrogen peroxide, which is a fast and exothermic reaction, is used as a model system in the field of heat transfer or thermal safety. ${ }^{5,12-15}$ Furthermore, the use of hydrogen peroxide as an oxidizing agent in industry is growing because it is eco-friendly. ${ }^{16-17}$ Hydrogen peroxide is used in different fields such as waste/water/effluent treatment, paper/pulp/textile bleaching, chemical synthesis, mining/metallurgy or detergents. In 2006, the annual production was around 2.2 million tons ${ }^{18}$ and 4.5 million tons in $2014 .^{17}$ 
Decomposition of hydrogen peroxide can occur in the presence of some ppm of metals leading to thermal runaway accidents. ${ }^{19}$ In hydrometallurgical extraction, dissolution of metallic copper is done in an acidic hydrogen peroxide solution. ${ }^{20}$ During this dissolution, hydrogen peroxide is used as an oxidizing agent producing in fine copper (II) sulfate. ${ }^{21}$ For an economic reason, the decomposition of hydrogen peroxide by copper (II) sulfate should be lowered. ${ }^{22}$

In this manuscript, the decomposition of hydrogen peroxide by copper (II) sulfate was used as a test system. A kinetic model was built to estimate the intrinsic kinetic parameters based on the work of Perez-Benito. ${ }^{23}$ The establishment of such kinetic model for an adiabatic reactor is scarce in the literature. ${ }^{24,25}$ Then, a comparison is done between the values of $\mathrm{TMR}_{\mathrm{ad}}\left(\mathrm{T}_{\mathrm{p}}\right), \mathrm{T}_{\mathrm{D} 24}$ and $\mathrm{T}_{\mathrm{D} 8}$ at different process temperatures obtained from the intrinsic kinetic model and the zero-order kinetic model.

Different calorimeters can be used to determine these safety parameters: accelerating rate calorimeters (ARC), ${ }^{5,24,26-27}$ vent sizing package (VSP), ${ }^{28-30}$ Phi-Tech II, ${ }^{6,8}$ differential scanning calorimetry, ${ }^{5,26-28,30}$ or advanced reactive system screening tool (ARSST). ${ }^{10,31-35,25}$ Experiments performed with this calorimeter can be done under adiabatic or near-adiabatic conditions with a low $\Phi$-factor. ${ }^{1,36}$

Decomposition study of compounds in liquid phase can be difficult because temperature increase can lead to evaporation and hence to the diminution of the reaction mass. Fauske and Associates have developed the Advanced Reactive System Screening Tool (ARSST), with a low $\Phi$-factor (ca. 1.04), where it is possible to work under high inert pressure to limit the evaporation. The other benefit of ARSST compared to ARC or VSP calorimeters is to provide fast screening of 
exothermic reactions. ${ }^{19,37}$ The ARSST system was used for this study to measure the reaction temperature. 


\section{EXPERIMENTAL SECTION}

The decomposition of hydrogen peroxide (33 wt.\% in water, VWR) in a sulfuric acid (95-98 wt.\%, ITW companies) solution in the presence of copper sulfate (99 wt.\%, VWR), was investigated in the ARSST unit. The ARSST unit, as shown in Figure 1, is used to characterize chemical system that could lead to rapid pressure and temperature rise.

The reactor is essentially composed of two compartments. The first compartment is a test cell assembly including a glass test cell for the reaction mixture with a volume capacity of $10 \mathrm{~mL}$. In the first step, a solution of copper (II) sulfate and sulfuric acid was added into the test cell, then hydrogen peroxide at room temperature. The glass test cell is surrounded by a heater and insulated by foil wrap and glass fiber. Inside the glass test cell, there are a thermocouple $\left(T_{1}\right)$ in contact with the reaction mixture, a stir bar and a fill tube. Stirring of the reaction mixture is ensured by a magnetic stirrer system.

The test cell assembly is inserted into the second compartment, which is a $450 \mathrm{~mL}$ containment vessel made of stainless steel. A second thermocouple $\left(\mathrm{T}_{2}\right)$ is placed in the upper part of the second compartment to measure the temperature in the headspace and a pressure transducer is used to follow the evolution of the pressure in the headspace. Thus, experiments were carried out in the open test cell in closed containment.

Nitrogen was used, as an inert gas, to work under mid-pressure (20-50 bar) to minimize the evaporation of the liquid mixture. Different initial pressures were tested to investigate the effect on the kinetics of decomposition. The pressure in the headspace increases because of the production of non-condensable products like oxygen and the temperature increase. 
The time to charge the test cell and to start the heater is less than 10 minutes, and during that time there is no significant decomposition of hydrogen peroxide.

Different background heating rates were tested $\left(0.6-4^{\circ} \mathrm{C} / \mathrm{min}\right)$. ARSST can perform experiments under near-adiabatic conditions, working on the basis of heat loss compensation principle. ${ }^{25,32}$ The $\Phi$-factor values for the different experiments carried out varied between 1.04 and 1.05. The boiling point of water at 35 bar was estimated to be ca. $242^{\circ} \mathrm{C}$ by using Aspen plus software v9.0 (Aspen Technology, Inc.) and by following the method described in the book of Jana using the thermodynamic method of Wilson. ${ }^{38}$ The reaction mixture used during these experiments was mainly composed of water. For that reason, the stop criterion for the different experiments was fixed to $200^{\circ} \mathrm{C}$, i.e., before the boiling point. 


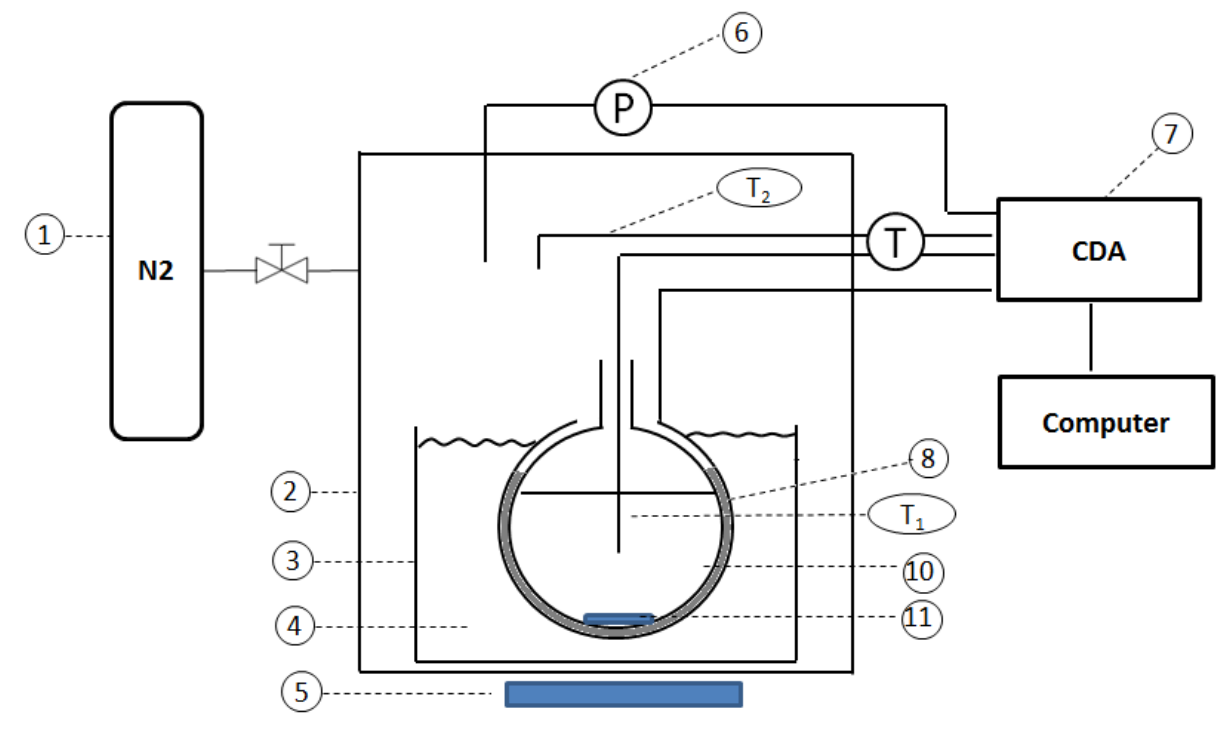

1- Inert gas supply $\left(\mathrm{N}_{2}\right)$.

2- $450 \mathrm{~mL}$ containment vessel made of stainless steel.

3- Test cell assembly made of aluminum.

4- Glass fiber.

5- Magnetic stir plate.

6- Pressure transducer.

7- Control and Data Acquisition.

8- Heater belt.

9- $\mathrm{T}_{1}$ and $\mathrm{T}_{2}-$ Thermocouples.

10- Glass test cell.

11- Magnetic stirring bar.

Figure 1. Schematical representation of the experimental setup of ARSST. 


\section{RESULTS AND DISCUSSION}

The first chapter focuses on the main parameters influencing the decomposition of hydrogen peroxide in the ARSST unit by showing the evolution of the measured temperature versus time. Based on these preliminary results and the literature, an intrinsic kinetic model was built and described in the second chapter. The methodology to determine $\mathrm{T}_{\text {onset }}$ and the safety parameters $\left(\mathrm{TMR}_{\mathrm{ad}}, \mathrm{T}_{\mathrm{D} 24}\right.$ and $\left.\mathrm{T}_{\mathrm{D} 8}\right)$ by using the zero-order assumption is explained in the Supporting Information. The standard deviation for $\mathrm{T}_{\text {onset }}$ was found to be $0.11^{\circ} \mathrm{C}$ showing the repeatability of the experiments. The last chapter compares the $\mathrm{TMR}_{\mathrm{ad}}$ values obtained from the zero-order approach and the ones obtained by simulation using the intrinsic kinetic constants under adiabatic conditions.

\subsection{Parameters influencing the decomposition of hydrogen peroxide}

From a kinetic viewpoint, the decomposition of hydrogen peroxide is influenced by temperature and the concentrations of catalyst, hydrogen peroxide and sulfuric acid. ${ }^{22,39-40}$ Calorimeter parameters such as the background heating rate and the initial pressure of nitrogen (inert gas) could also have an influence on the kinetics of decomposition. During this study, we have varied these different parameters to measure their influence on the temperature increase and the value of $\mathrm{TMR}_{\mathrm{ad}}$. The pressure information provided by the ARSST is more qualitative than quantitative due to the high volume of the gas phase compared to the liquid phase. For that reason, the evolution of pressure was not used to determine the kinetic and thermodynamic constants during the parameter estimation stage. Due to space limitation, the evolution of pressure in the gas phase can be found in Supporting Information. 


\subsubsection{Calorimeter parameters}

Different background heating rates were tested in the range $1-4^{\circ} \mathrm{C} / \mathrm{min}$. As the background heating rate increases, the kinetics of decomposition is faster (Figure 2). The pressure evolution for experiments displayed by Figure 2 is displayed in Figure S3 (Supporting Information).

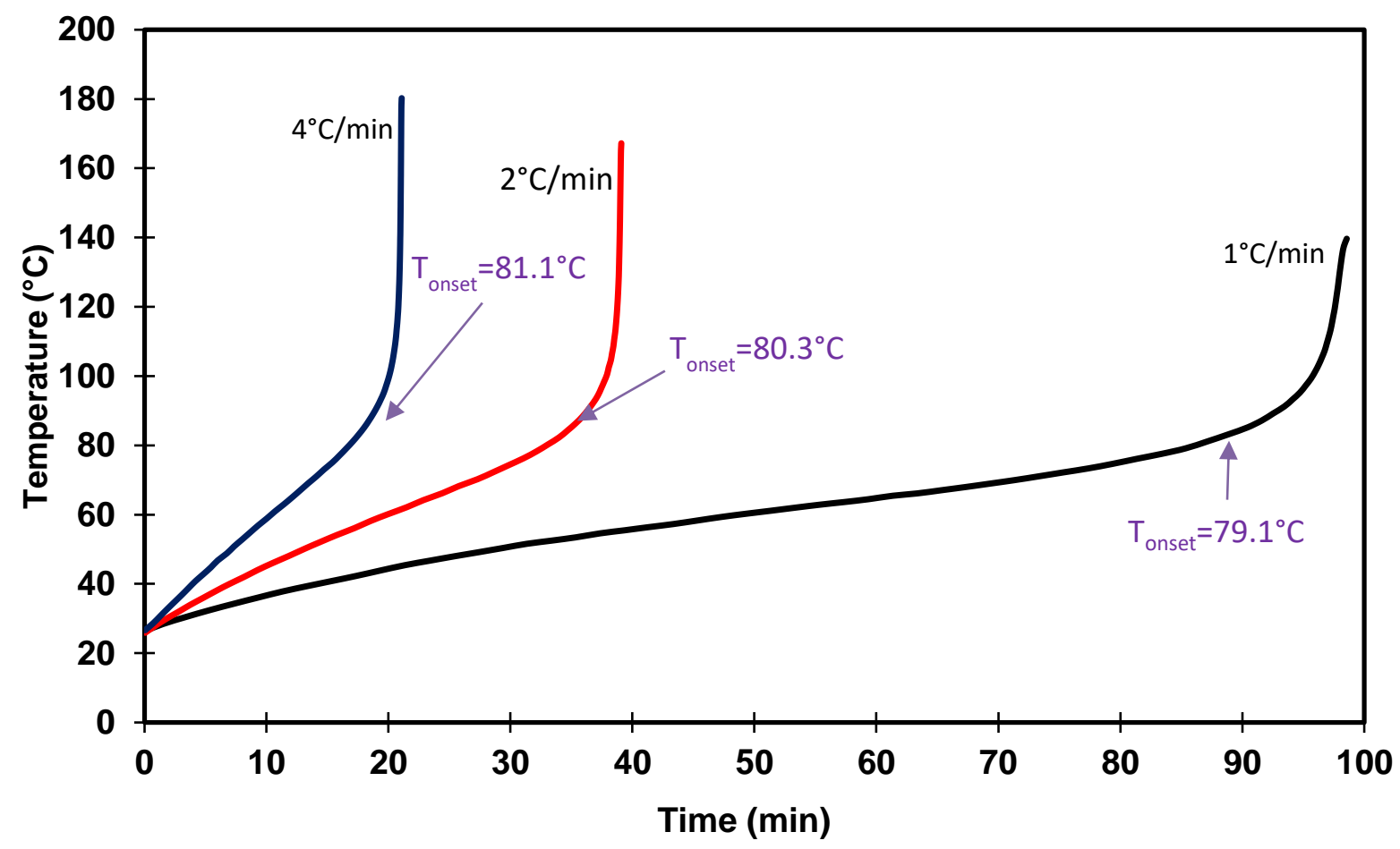

Figure 2. Influence of the background heating rate on reaction temperature at an initial pressure of ca 36 bar and with $\left[\mathrm{H}_{2} \mathrm{O}_{2}\right]_{0}=10.96 \mathrm{~mol} / \mathrm{L},\left[\mathrm{CuSO}_{4}\right]_{0}=0.04 \mathrm{~mol} / \mathrm{L}$ and $\left[\mathrm{H}_{2} \mathrm{SO}_{4}\right]_{0}=0.72 \mathrm{~mol} / \mathrm{L}$.

As the background heating rate increases, the time to reach $\mathrm{T}_{\text {onset }}$ is lower. When the background heating rate increases, it is logical to reach faster $\mathrm{T}_{\text {onset. }}$ The results of $\mathrm{T}_{\mathrm{D} 24}$ and $\mathrm{T}_{\mathrm{D} 8}$ by using the zero-order approach are presented and compared to the ones obtained from the intrinsic model in the last chapter (Table 1). Chapter 3.3 shows the evolution of $\mathrm{TMR}_{\mathrm{ad}}\left(\mathrm{T}_{\mathrm{P}}\right)$ obtained from the intrinsic kinetic and zero-order model corresponding to this set of experiments. 
By varying the initial pressure of nitrogen between 27.5 and 41 bar, the kinetics of hydrogen peroxide decomposition was similar. Thus, one can conclude that the initial pressure does not have a significant influence on $\mathrm{TMR}_{\mathrm{ad}}\left(\mathrm{T}_{\mathrm{p}}\right)$ within the initial pressure range 27.5-41 bar. Casson et al. ${ }^{39}$ have also made this observation by using the Phi-TEC II.

\subsubsection{Reaction conditions parameters}

Decomposition of hydrogen peroxide is sensitive to $\mathrm{pH}$. Hydrogen peroxide is stable in acidic environment. ${ }^{40}$ In the absence of sulfuric acid in the reaction mixture, the decomposition is faster. The influence of sulfuric acid on the mechanism of decomposition can be very complex to take into account due the different degrees of oxidation of the metals. For that reason, the comparison between the safety parameters obtained from the zero-order and the intrinsic kinetic models was done by using one concentration of sulfuric acid, i.e., $\left[\mathrm{H}_{2} \mathrm{SO}_{4}\right]=0.72 \mathrm{~mol} / \mathrm{L}$. At lower sulfuric acid concentration, the decomposition might be too fast for the acquisition system.

As the concentration of $\mathrm{CuSO}_{4}$ increases, the kinetics of $\mathrm{H}_{2} \mathrm{O}_{2}$ decomposition is faster (Figure 3). Hence, when the concentration of copper increases, the values of $\mathrm{T}_{\mathrm{D} 24}$ and $\mathrm{T}_{\mathrm{D} 8}$, by using the zeroorder model, decrease (Table 2). In the absence of copper (II) sulfate, the value of $\mathrm{T}_{\mathrm{D} 24}$ is ca. 3.5 higher than in the presence of this salt (Table 2). These experiments show the catalytic effect of copper (II). A comparison between the safety parameters obtained from the intrinsic kinetic model and zero-order approach is discussed in the last chapter. The evolution of pressure for experiments displayed in Figure 3 was inserted in Supporting information (Figure S4). The trend is similar for the evolution of temperature and pressure. 


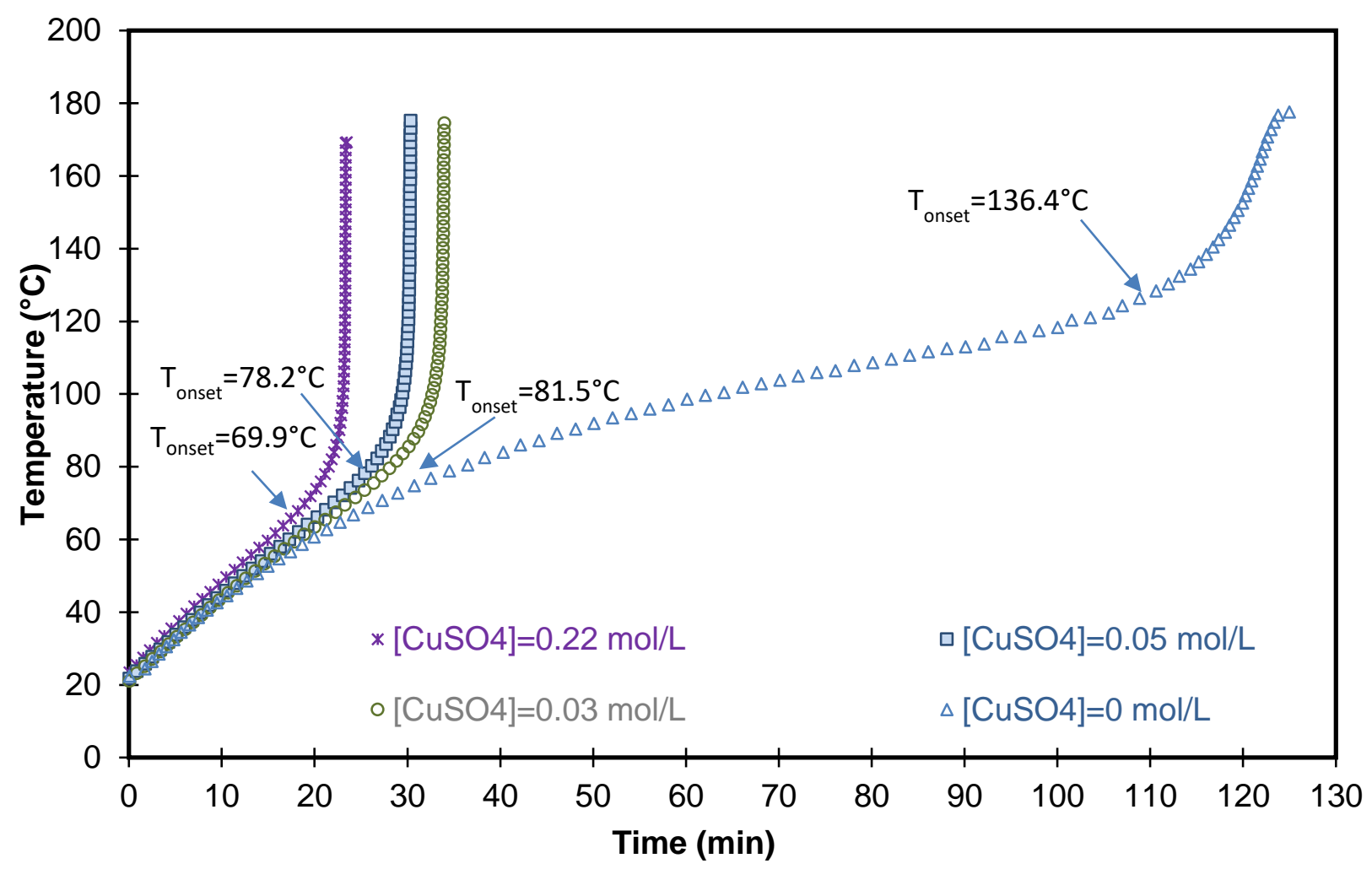

Figure 3. Effect of $\mathrm{CuSO}_{4}$ concentration on reaction temperature with the following initial experimental conditions: background heating rate of $2^{\circ} \mathrm{C} / \mathrm{min},\left[\mathrm{H}_{2} \mathrm{O}_{2}\right]_{0}=10.96 \mathrm{~mol} / \mathrm{L}$, and

$$
\left[\mathrm{H}_{2} \mathrm{SO}_{4}\right]_{0}=0.72 \mathrm{~mol} / \mathrm{L} \text {. }
$$

The concentration of hydrogen peroxide has an influence on the values of $\mathrm{T}_{\mathrm{D} 24}$ and $\mathrm{T}_{\mathrm{D} 8}$, by using the zero-order model (Figure 4). When the concentration of $\mathrm{H}_{2} \mathrm{O}_{2}$ increases, the values of $\mathrm{T}_{\mathrm{D} 24}$ decrease (Table 3). This observation is logical because the rate of hydrogen peroxide decomposition depends on the concentration of hydrogen peroxide. The safety parameters obtained from the intrinsic kinetic model and zero-order approach is discussed in the last chapter. The evolution of pressure for experiments displayed in Figure 3 was inserted in Supporting Information (Figure S5). The trend is similar for the evolution of temperature and pressure. As the concentration of hydrogen peroxide increase, the pressure increase is faster and higher. 


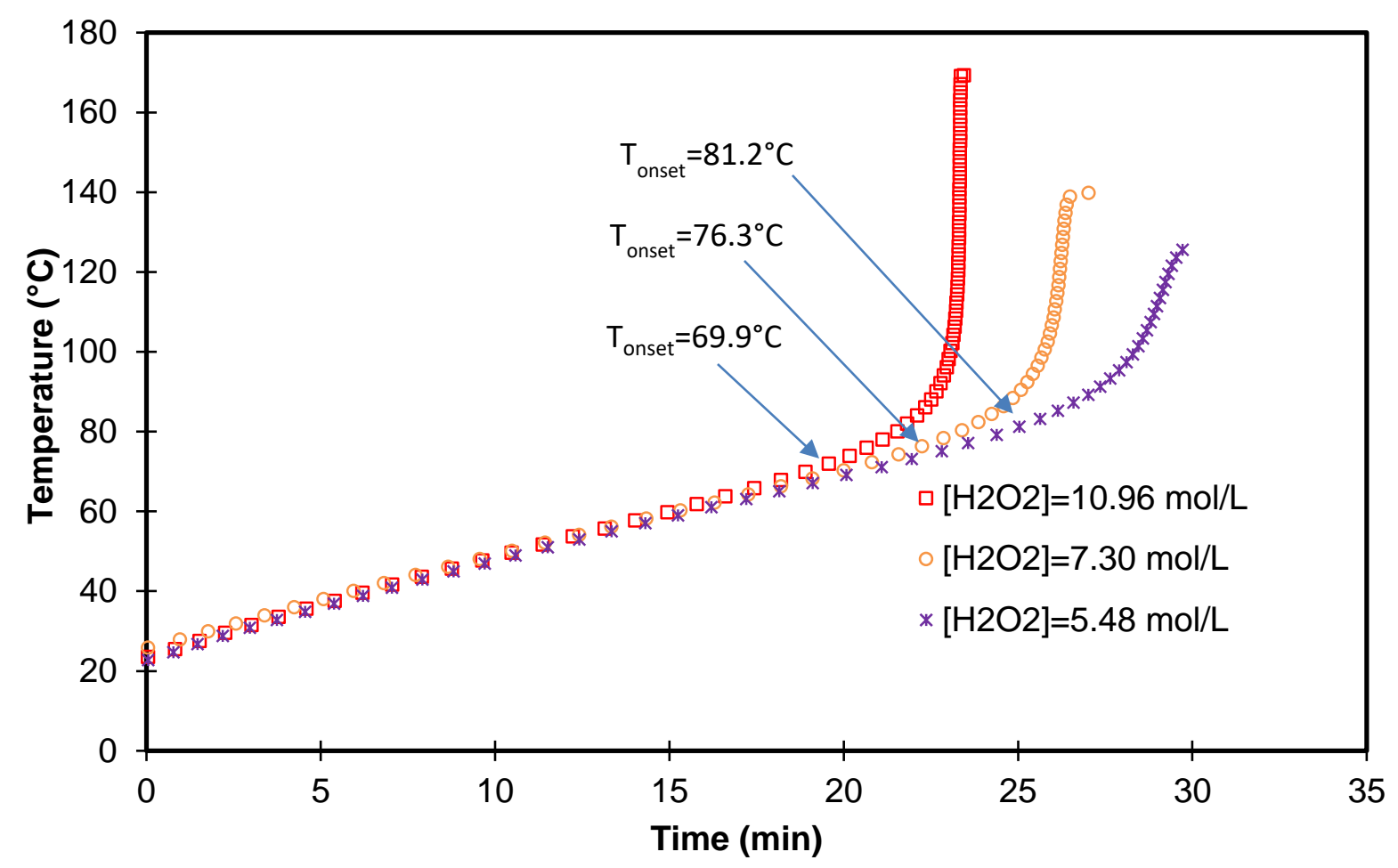

Figure 4. Effect of $\mathrm{H}_{2} \mathrm{O}_{2}$ concentration on reaction temperature with the following initial experimental conditions: background heating rate of $2^{\circ} \mathrm{C} / \mathrm{min},\left[\mathrm{CuSO}_{4}\right]_{0}=0.22 \mathrm{~mol} / \mathrm{L}$, and $\left[\mathrm{H}_{2} \mathrm{SO}_{4}\right]_{0}=0.72 \mathrm{~mol} / \mathrm{L}$. 


\subsection{Intrinsic kinetic model for hydrogen peroxide decomposition}

The zero-order model was explained in Supporting Information. In this section, the kinetics of the reaction system, the mass and energy balance and the parameter estimation are presented. To estimate the intrinsic kinetic and thermal parameters for the decomposition of hydrogen peroxide by copper (II) sulfate, a series of 9 experiments with the ARSST was performed (Table S1, Supporting Information).

\subsubsection{Kinetics}

One should distinguish two routes of hydrogen peroxide decomposition: thermal or spontaneous decomposition without the aid of copper and the catalyzed decomposition by copper.

The overall reaction can be written as

$\mathrm{H}_{2} \mathrm{O}_{2} \longrightarrow \mathrm{H}_{2} \mathrm{O}+1 / 2 \mathrm{O}_{2}$

The kinetics of hydrogen peroxide decomposition can be written as

$\mathrm{R}_{\text {Decomposition }}=\mathrm{R}_{\text {Spontaneous }}+\mathrm{R}_{\text {Catalyzed by } \mathrm{Cu}(\mathrm{II})}$

A first order reaction was assumed for the spontaneous decomposition of hydrogen peroxide

$\mathrm{R}_{\text {Spontaneous }}=\mathrm{k}_{\text {Spontaneous }} \cdot\left[\mathrm{H}_{2} \mathrm{O}_{2}\right]$

Decomposition of hydrogen peroxide by copper (II) undergoes a complex mechanism. Based on the article of Perez-Benito, ${ }^{23}$ the detailed kinetics of decomposition catalyzed by copper (II) $\mathrm{R}_{\text {Catalyzed by Cu(II) }}$ can be expressed as:

$\mathrm{R}_{\text {Catalyzed by } \mathrm{Cu}(\mathrm{II})}=2 \cdot \mathrm{k}_{\mathrm{A}} \cdot\left[\mathrm{Cu}^{2+}\right] \cdot\left[\mathrm{H}_{2} \mathrm{O}_{2}\right]^{2}+2 \cdot \mathrm{k}_{\mathrm{B}} \cdot\left[\mathrm{Cu}^{2+}\right]^{1 / 2} \cdot\left[\mathrm{H}_{2} \mathrm{O}_{2}\right]$ 
where, $\mathrm{k}_{\mathrm{A}}$ and $\mathrm{k}_{\mathrm{B}}$ are two rate constants. These parameters were estimated with their associated activation energies during the modeling stage.

\subsubsection{Mass and energy balance}

Experiments were performed in an open cell where decomposition reaction produces noncondensable product, i.e., $\mathrm{O}_{2}$. Thus, molar balance of an arbitrary compound (i) in the liquid phase can be expressed by

$\mathrm{r}_{\mathrm{i}} \cdot \mathrm{V}_{\text {liq }}=\frac{\mathrm{dn}_{\mathrm{i}}}{\mathrm{dt}}+\dot{\mathrm{n}}_{\mathrm{i}, \text { out }}$

where, $r_{i}$ is the kinetics of formation or disappearance of compound (i), $V_{\text {liq }}$ is the volume of the liquid phase, $\frac{d n_{i}}{d t}$ is the accumulation of compound $i$ in the liquid phase and $\dot{n}_{i, \text { out }}$ is the outlet interfacial component flux.

As mentioned in the experimental section, the stop criterion was $200^{\circ} \mathrm{C}$, which is lower than the boiling point at 35 bar. Thus, the evaporation of the reaction mixture can be assumed to be negligible. Hence, the term $\dot{\mathrm{n}}_{\mathrm{i} \text {,out }}$ is equal to zero for water and hydrogen peroxide, i.e., $\dot{\mathrm{n}}_{\mathrm{H}_{2} \mathrm{O}_{2} \text {,out }}=$ $\dot{\mathrm{n}}_{\mathrm{H}_{2} \mathrm{O}, \mathrm{out}}=0 \mathrm{~mol} / \mathrm{s}$.

The variation of the mass is due to the release of oxygen in the headspace of the ARSST unit. The liquid-gas mass transfer for oxygen is assumed to be fast, then $\mathrm{n}_{\mathrm{O}_{2}, \text { liq }} \rightarrow 0 \mathrm{~mol} \Leftrightarrow \frac{\mathrm{dn}_{\mathrm{O}_{2}, \mathrm{liq}}}{\mathrm{dt}}=$ $0 \mathrm{~mol} / \mathrm{s}$.

The accumulation of oxygen in the headspace can be written as $\frac{\mathrm{dn}_{\mathrm{O}_{2}, \text { gas }}}{\mathrm{dt}}=\dot{\mathrm{n}}_{\mathrm{O}_{2}, \text { out }}$. 
The number of moles in the gas phase was expressed by using the ideal gas law. Thus, the mass balance for oxygen in the gas phase can be expressed as

$\frac{\mathrm{dp}_{\mathrm{O}_{2}}}{\mathrm{dt}}=+0.5 \cdot \frac{\mathrm{R}_{\text {Decomposition }} \cdot \mathrm{V}_{\mathrm{liq}} \cdot \mathrm{R} \cdot \mathrm{T}_{2}}{\mathrm{~V}_{\text {gas }}}$

where, $\mathrm{p}_{\mathrm{O}_{2}}$ is the partial pressure of oxygen in the headspace. The temperature $\left(\mathrm{T}_{2}\right)$ in the gas phase can be assumed constant (Figure S1b, Supporting Information).

The mass balances for water and hydrogen peroxide can be written as

$\frac{\mathrm{dC}_{\mathrm{H}_{2} \mathrm{O}_{2}}}{\mathrm{dt}}=-\mathrm{R}_{\text {Decomposition }}-\frac{\mathrm{C}_{\mathrm{H}_{2} \mathrm{O}_{2}}}{\mathrm{~V}_{\text {liq }}} \cdot\left(-\frac{0.5 \cdot \mathrm{M}_{\mathrm{O}_{2}} \cdot \mathrm{R}_{\text {Decomposition }} \cdot \mathrm{V}_{\text {liq }}}{\rho_{\text {liq }}}\right)$

$\frac{\mathrm{dC}_{\mathrm{H}_{2} \mathrm{O}}}{\mathrm{dt}}=\mathrm{R}_{\text {Decomposition }}-\frac{\mathrm{C}_{\mathrm{H}_{2} \mathrm{O}}}{\mathrm{V}_{\text {liq }}} \cdot\left(-\frac{0.5 \cdot \mathrm{M}_{\mathrm{O}_{2}} \cdot \mathrm{R}_{\text {Decomposition }} \cdot \mathrm{V}_{\text {liq }}}{\rho_{\text {liq }}}\right)$

A detailed explanation of the equation derivation is explained in Supporting Information.

Energy balance was expressed by

$\left(m_{\text {liq }} \cdot \widehat{C}_{P_{\text {liq }}}+m_{\text {insert }} \cdot \widehat{C}_{P_{\text {insert }}}\right) \cdot \frac{d T_{1}}{d t}=q_{r}+q_{\text {electrical }}$

$\Leftrightarrow \Phi \cdot \mathrm{m}_{\text {liq }} \cdot \widehat{\mathrm{C}}_{\mathrm{P}_{\text {liq }}} \cdot \frac{\mathrm{dT} \mathrm{T}_{1}}{\mathrm{dt}}=\mathrm{q}_{\mathrm{r}}+\mathrm{q}_{\text {electrical }}$

$\Leftrightarrow \frac{\mathrm{dT}_{1}}{\mathrm{dt}}=\frac{\mathrm{q}_{\mathrm{r}}}{\Phi \cdot \mathrm{m}_{\mathrm{liq}} \cdot \widehat{C}_{\mathrm{P}}}+\beta_{\text {electrical }}$

where, $\Phi$ is the thermal inertia of the system, a typical value is 1.04 and $\beta_{\text {electrical }}$ is the background heating rate. The term $\mathrm{q}_{\mathrm{r}}$ is the heat flow-rate due to chemical reactions. Heat capacity of the reaction mixture $\widehat{\mathrm{C}}_{\mathrm{P}_{\text {liq }}}$ was calculated as $\widehat{\mathrm{C}}_{\mathrm{P}_{\text {liq }}}\left(\mathrm{T}_{1}\right)=\sum_{\mathrm{i}} \mathrm{W}_{\mathrm{i}} \cdot \widehat{\mathrm{C}}_{\mathrm{P}_{\mathrm{i}}}\left(\mathrm{T}_{1}\right)$. The evolution of $\widehat{\mathrm{C}}_{\mathrm{P}_{\mathrm{i}}}$ for water 
and hydrogen peroxide with temperature was determined from Aspen plus software v9.0 (Aspen Technology, Inc.) using the Wilson thermodynamic model. (Figure S6, Supporting Information).

The $\Phi$-factor is equal to $\frac{\left(\mathrm{m}_{\text {liq }} \cdot \widehat{C}_{\mathrm{P}_{\text {liq }}}+\mathrm{m}_{\text {insert }} \widehat{C}_{\mathrm{C}_{\text {insert }}}\right)}{m_{\text {liq }} \cdot \widehat{C}_{\mathrm{P}_{\text {liq }}}}$, where $\widehat{\mathrm{C}}_{\mathrm{P}_{\text {insert }}}$ is the heat-capacity of the test cell and equal to $0.83 \mathrm{~kJ} \cdot \mathrm{kg}^{-1} \cdot \mathrm{K}^{-1}$ (value given by the manufacturer).

Heat-flow rate due to chemical reactions was expressed as

$\mathrm{q}_{\mathrm{r}}\left(\mathrm{T}_{1}\right)=\left(-\mathrm{R}_{\text {Spontaneous }} \cdot \Delta \mathrm{H}_{\mathrm{R}, \text { Spontaneous }}-\mathrm{R}_{\text {Catalyzed by Cu(II) }} \cdot \Delta \mathrm{H}_{\mathrm{R}, \text { Catalyzed by Cu(II) }}\right) \cdot \mathrm{V}_{\text {liq }}(10)$

According to several authors, ${ }^{41-42}$ the enthalpy of hydrogen peroxide decomposition without catalyst is of ca. $-98 \mathrm{~kJ} / \mathrm{mol}$. Thus, the value of $-98 \mathrm{~kJ} / \mathrm{mol}$ was used for the spontaneous decomposition reaction enthalpy $\Delta \mathrm{H}_{\mathrm{R}, \text { Spontaneous. The reaction enthalpy for the catalyzed }}$

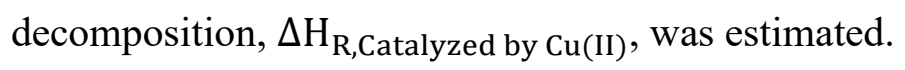




\subsubsection{Kinetic model: parameter estimation}

ModEst software ${ }^{43}$ based on Fortran code was used to estimate: $\mathrm{k}_{\text {spontaneous, }} \mathrm{Ea}_{\text {spontaneous }}, \mathrm{k}_{\mathrm{A}}, \mathrm{Ea}_{\mathrm{A}}$, $\Delta \mathrm{H}_{\mathrm{R}, \text { Catalyzed by } \mathrm{Cu}(\mathrm{II})}, \mathrm{k}_{\mathrm{B}}$ and $\mathrm{Ea}_{\mathrm{B}}$.

The temperature dependences of the rate constants $\left(\mathrm{k}_{\mathrm{A}}\right.$ and $\left.\mathrm{k}_{\mathrm{B}}\right)$ was described by a modified Arrhenius equation,

$\mathrm{k}=\mathrm{k}_{\mathrm{ave}} \cdot \exp \left(\frac{-\mathrm{E}_{\mathrm{a}}}{\mathrm{R}} \cdot\left(\frac{1}{\mathrm{~T}}-\frac{1}{\mathrm{~T}_{\mathrm{ave}}}\right)\right)$

where, $\mathrm{k}_{\mathrm{ave}}=\mathrm{A} \cdot \mathrm{e}^{\left(\frac{-\mathrm{E}_{\mathrm{a}}}{\mathrm{R} \cdot \mathrm{T}_{\mathrm{ave}}}\right)}$, and $\mathrm{T}_{\mathrm{ave}}$ is the average temperature of the set of experiments. This modification was done to decrease the correlation between the activation energy and the preexponential factor.

The coefficient of determination of the model was expressed as: $\mathrm{R}^{2}=1-\frac{\left(\mathrm{y}_{\mathrm{i}}-\widehat{\mathrm{y}}_{\mathrm{i}}\right)^{2}}{\left(\mathrm{y}_{\mathrm{i}}-\overline{\mathrm{y}}_{\mathrm{i}}\right)^{2}}$, where $\bar{y}$ was the mean value of the experimental observables, $\hat{y}_{\mathrm{i}}$ was the observable simulated by the model and $y_{i}$ was the experimental observable.

The objective function $\omega$ was calculated as $=\sum_{i}\left(y_{i}-\hat{y}_{i}\right)^{2}$.

The objective function was minimized by using simplex and Levenberg-Marquardt algorithms. Ordinary differential equations 6-9 were solved out by backward difference method. The reaction temperature $\left(\mathrm{T}_{1}\right)$ was used as an observable. As discussed in paragraph 3.1.1, the pressure measurement is not accurate due to the high volume of the gas phase compare to the liquid phase. Thus, the pressure rise was not used as an observable. 
The kinetic modeling strategy and the statistical results are presented in the Supporting Information (Figures S7-S9, Tables S2-S3). To minimize the number of estimated parameters, two models were built: one in the absence of copper (II) to determine the spontaneous decomposition kinetic parameters and one in the presence of copper (II) to determine the catalyzed decomposition kinetic parameters. Based on this model, it is possible to determine $\mathrm{TMR}_{\mathrm{ad}}$ at any process temperature and also $\mathrm{T}_{\mathrm{D} 24}$ and $\mathrm{T}_{\mathrm{D} 8}$. 
3.3 Evolution of $\mathrm{TMR}_{\mathrm{ad}}$ from the zero-order and the intrinsic kinetic model.

By using the estimated kinetic and thermodynamic constants (Tables S2-S3, Supporting Information), we have simulated the evolution of the reaction temperature under real adiabatic conditions, i.e., $\Phi=1$ and without electrical heating. Based on this simulation stage, it is possible to determine the values of $\mathrm{TMR}_{\mathrm{ad}}\left(\mathrm{T}_{\mathrm{P}}\right), \mathrm{T}_{\mathrm{D} 24}$ and $\mathrm{T}_{\mathrm{D} 8}$ from the intrinsic kinetic model and by using the initial concentrations of the experiments described in chapters 3.1.1 and 3.1.2.

Tables 1-3 propose a comparison between the values of $\mathrm{T}_{\mathrm{D} 24}$ and $\mathrm{T}_{\mathrm{D} 8}$ obtained by using the zeroorder and the intrinsic kinetic model. The difference between the values of these safety parameters provided by the zero-order approximation and the intrinsic kinetic model is introduced.

The use of the zero-order approximation is widely accepted by the safety community because it overestimates the risk. In this study, one should notice that the zero-order model does not overestimate all the time the safety parameter. In other words, the values of $\mathrm{T}_{\mathrm{D} 24}$ or $\mathrm{T}_{\mathrm{D} 8}$ obtained from the zero-order model are not always lower than the ones obtained from the intrinsic kinetic model. The difference on $\mathrm{T}_{\mathrm{D} 24}$ or $\mathrm{T}_{\mathrm{D} 8}$ from these two models vary between ca. $-9^{\circ} \mathrm{C}$ to ca. $+23^{\circ} \mathrm{C}$.

Figure 5 and Table 1 compare the safety parameters obtained from the zero-order at different background heating rates and from the intrinsic kinetic model. One can notice that for a $\beta$ equal to $2^{\circ} \mathrm{C} / \mathrm{min}, \mathrm{TMR}_{\mathrm{ad}}$ values obtained from both models are similar. From Table 1, one can notice that the background heating rate has a significant influence on the values of $\mathrm{T}_{\mathrm{D} 24}$ and $\mathrm{T}_{\mathrm{D} 8}$ obtained from the zero-order approximation. For these three experiments performed under the same experimental conditions but at different background heating rates, the values of $\mathrm{T}_{\mathrm{D} 24}$ and $\mathrm{T}_{\mathrm{D} 8}$ should be similar. However, the absolute difference is higher than $5^{\circ} \mathrm{C}$ for a background heating rate of 1 and $4^{\circ} \mathrm{C} / \mathrm{min}$. 
At low value of background heating rate, the determination of $\mathrm{T}_{\text {onset }}$ is difficult because we do not observe a clear temperature increase due to chemical reactions (Figure 2). For example, when $\beta$ is of $1^{\circ} \mathrm{C} / \mathrm{min}$ the time to reach $\mathrm{T}_{\text {onset }}$ is 85 minutes (Table 1 ).

At higher value of $\beta$, there is an overestimation of the safety parameter by the zero-order model, which do not lead to a dangerous situation. This overestimation is due to the fact that the electrical part is not negligible on the temperature increase, making difficult the detection of $\mathrm{T}_{\text {onset. }}$.

For this reaction system, a background heating rate of $2{ }^{\circ} \mathrm{C} / \mathrm{min}$ gives similar results for both models as shown by Figure 5.

Table 1. Influence of the background heating rates on $\mathrm{T}_{\text {onset, }} \mathrm{t}_{\mathrm{onset}}, \mathrm{T}_{\mathrm{D} 24}$ and $\mathrm{T}_{\mathrm{D} 8}$ by using the zero-order model (experiments illustrated by Figure 2) and comparison with the values obtained from the intrinsic kinetic model.

\begin{tabular}{|c|c|c|c|c|c|c|c|c|}
\hline \multirow{2}{*}{$\begin{array}{l}\text { Background } \\
\text { heating } \\
\text { rate }\left({ }^{\circ} \mathrm{C} / \mathrm{min}\right)\end{array}$} & \multirow[b]{2}{*}{$\begin{array}{l}\mathrm{T}_{\text {onset }} \\
\left({ }^{\circ} \mathrm{C}\right) \\
\end{array}$} & \multirow[b]{2}{*}{$\begin{array}{l}t_{\text {onset }} \\
(\min ) \\
\end{array}$} & \multicolumn{2}{|c|}{$\begin{array}{l}\text { ZERO- } \\
\text { ORDER }\end{array}$} & \multicolumn{2}{|c|}{$\begin{array}{l}\text { INTRINSIC } \\
\text { KINETIC }\end{array}$} & \multirow[b]{2}{*}{$\begin{array}{l}\text { Difference } \\
\mathrm{T}_{\mathrm{D} 24}\left({ }^{\circ} \mathrm{C}\right) \\
\end{array}$} & \multirow[b]{2}{*}{$\begin{array}{l}\text { Difference } \\
\mathrm{T}_{\mathrm{D} 8}\left({ }^{\circ} \mathrm{C}\right) \\
\end{array}$} \\
\hline & & & $\begin{array}{l}\mathrm{T}_{\mathrm{D} 24} \\
\left({ }^{\circ} \mathrm{C}\right) \\
\end{array}$ & $\begin{array}{l}\mathrm{T}_{\mathrm{D} 8} \\
\left({ }^{\circ} \mathrm{C}\right) \\
\end{array}$ & $\begin{array}{l}\mathrm{T}_{\mathrm{D} 24} \\
\left({ }^{\circ} \mathrm{C}\right) \\
\end{array}$ & $\begin{array}{l}\mathrm{T}_{\mathrm{D} 8} \\
\left({ }^{\circ} \mathrm{C}\right) \\
\end{array}$ & & \\
\hline 1 & 79.1 & 85.3 & 31.7 & 41.6 & \multirow{3}{*}{23} & \multirow{3}{*}{37} & -8.7 & -4.6 \\
\hline 2 & 80.3 & 33.1 & 25.7 & 35.2 & & & -2.7 & 1.8 \\
\hline 4 & 81.1 & 17.1 & 16.6 & 26.8 & & & 6.4 & 10.2 \\
\hline
\end{tabular}




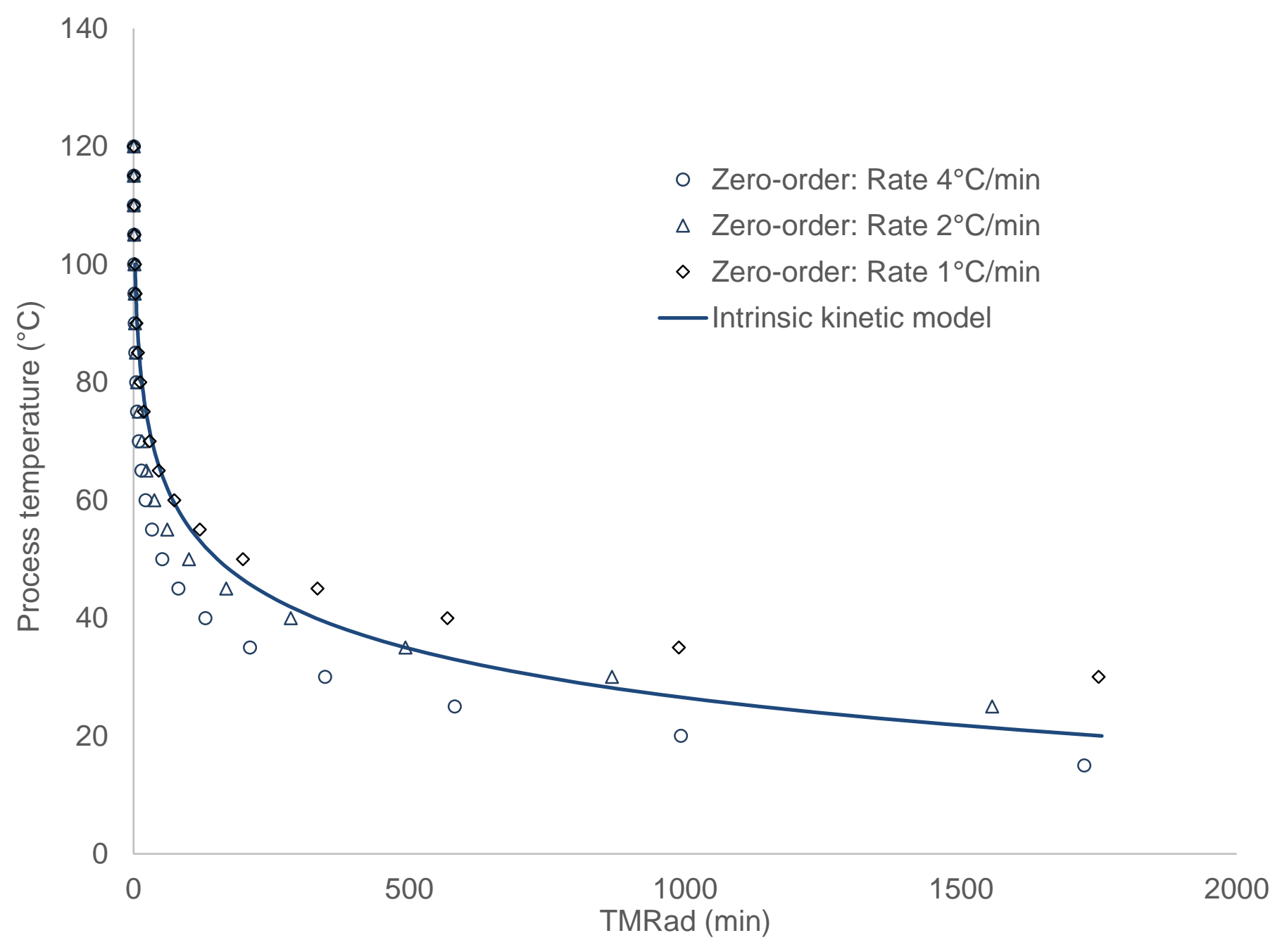

Figure 5. Evolution of $\mathrm{TMR}_{\mathrm{ad}}\left(\mathrm{T}_{\mathrm{P}}\right)$ by using zero-order approximation for different background heating rates and the intrinsic kinetic model. 
Figure 6 and Table 2 compare the safety parameters obtained from the zero-order and from the intrinsic kinetic model at different copper (II) sulfate concentrations. The zero-order model tends to overestimate the risk. Besides, one can notice that as the concentration of copper decreases, the difference between the safety parameters is more pronounced.

When the concentration of catalyst increases, the kinetics of decomposition is faster and the values of $T_{\mathrm{D} 24}$ and $T_{\mathrm{D} 8}$ are shorter. In the absence of copper, the difference between the two model is higher than $20^{\circ} \mathrm{C}$. The time to reach the $\mathrm{T}_{\text {onset }}$ is 115 minutes in absence of catalyst (Figure 3). As noticed in the previous chapter, when the time to reach $T_{\text {onset }}$ is relatively long, then the determination of this parameter is less accurate. 


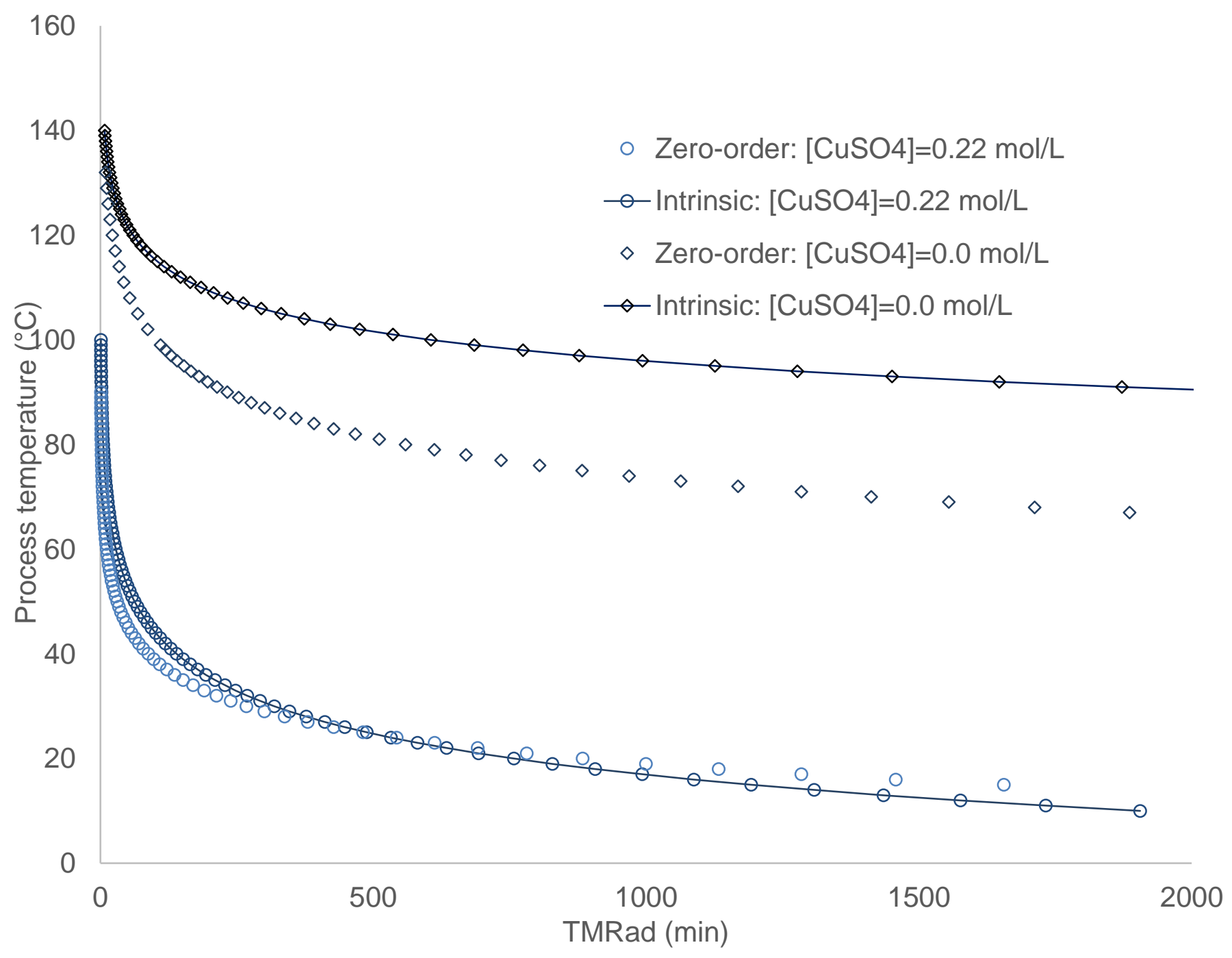

Figure 6. Evolution of $\mathrm{TMR}_{\mathrm{ad}}\left(\mathrm{T}_{\mathrm{P}}\right)$ by using zero-order approximation and intrinsic kinetic model for different copper (II) sulfate. 
Table 2. Influence of copper (II) sulfate on $\mathrm{T}_{\text {onset, }} \mathrm{t}_{\mathrm{onset}}, \mathrm{T}_{\mathrm{D} 24}$ and $\mathrm{T}_{\mathrm{D} 8}$ by using the zero-order model (experiments illustrated by Figure 3) and the intrinsic kinetic model.

\begin{tabular}{|c|c|c|c|c|c|c|c|c|c|}
\hline \multirow[b]{2}{*}{$\begin{array}{l}\text { Background } \\
\text { heating } \\
\text { rate }\left({ }^{\circ} \mathrm{C} / \mathrm{min}\right)\end{array}$} & \multirow[b]{2}{*}{$\begin{array}{c}{\left[\mathrm{CuSO}_{4}\right]} \\
(\mathrm{mol} / \mathrm{L})\end{array}$} & \multirow[b]{2}{*}{$\begin{array}{l}\text { Tonset } \\
\left({ }^{\circ} \mathrm{C}\right)\end{array}$} & \multirow[b]{2}{*}{$\begin{array}{l}\text { tonset } \\
\text { (min) }\end{array}$} & \multicolumn{2}{|c|}{$\begin{array}{l}\text { ZERO- } \\
\text { ORDER }\end{array}$} & \multicolumn{2}{|c|}{$\begin{array}{c}\text { INTRINSIC } \\
\text { KINETIC }\end{array}$} & \multirow[b]{2}{*}{$\begin{array}{l}\text { Difference } \\
\mathrm{T}_{\mathrm{D} 24}\left({ }^{\circ} \mathrm{C}\right)\end{array}$} & \multirow[b]{2}{*}{$\begin{array}{c}\text { Difference } \\
\mathrm{T}_{\mathrm{D} 8}\left({ }^{\circ} \mathrm{C}\right)\end{array}$} \\
\hline & & & & $\begin{array}{l}\mathrm{T}_{\mathrm{D} 24} \\
\left({ }^{\circ} \mathrm{C}\right)\end{array}$ & $\begin{array}{l}\mathrm{T}_{\mathrm{D} 8} \\
\left({ }^{\circ} \mathrm{C}\right)\end{array}$ & $\begin{array}{l}\mathrm{T}_{\mathrm{D} 24} \\
\left({ }^{\circ} \mathrm{C}\right)\end{array}$ & $\begin{array}{l}\mathrm{T}_{\mathrm{D} 8} \\
\left({ }^{\circ} \mathrm{C}\right)\end{array}$ & & \\
\hline \multirow{4}{*}{2} & 0.22 & 69.9 & 18.9 & 16.1 & 25 & 13 & 26 & -3.1 & 1.0 \\
\hline & 0.05 & 78.2 & 25.4 & 19.3 & 29.1 & 22 & 35 & 2.7 & 5.9 \\
\hline & 0.03 & 81.5 & 28.8 & 21.7 & 31.8 & 25 & 39 & 3.3 & 7.2 \\
\hline & 0 & 136.4 & 115.2 & 69.8 & 81.7 & 93 & 102 & 23.2 & 20.3 \\
\hline
\end{tabular}


Figure 7 and Table 3 compare the safety parameters obtained from the zero-order and from the intrinsic kinetic model at different hydrogen peroxide concentrations. Experiments were performed by using a background heating rate of $2^{\circ} \mathrm{C} / \mathrm{min}$ and a catalyst concentration of 0.22 $\mathrm{mol} / \mathrm{L}$ (Figure 4). Under these experimental conditions, i.e., $\beta=2{ }^{\circ} \mathrm{C} / \mathrm{min},\left[\mathrm{CuSO}_{4}\right]=0.22 \mathrm{~mol} / \mathrm{L}$ and $\left[\mathrm{H}_{2} \mathrm{SO}_{4}\right]=0.72 \mathrm{~mol} / \mathrm{L}$, the values of $\mathrm{T}_{\mathrm{D} 24}$ and $\mathrm{T}_{\mathrm{D} 8}$ obtained by the two models are similar in the hydrogen peroxide concentration range of 5.48-10.96 mol/L.

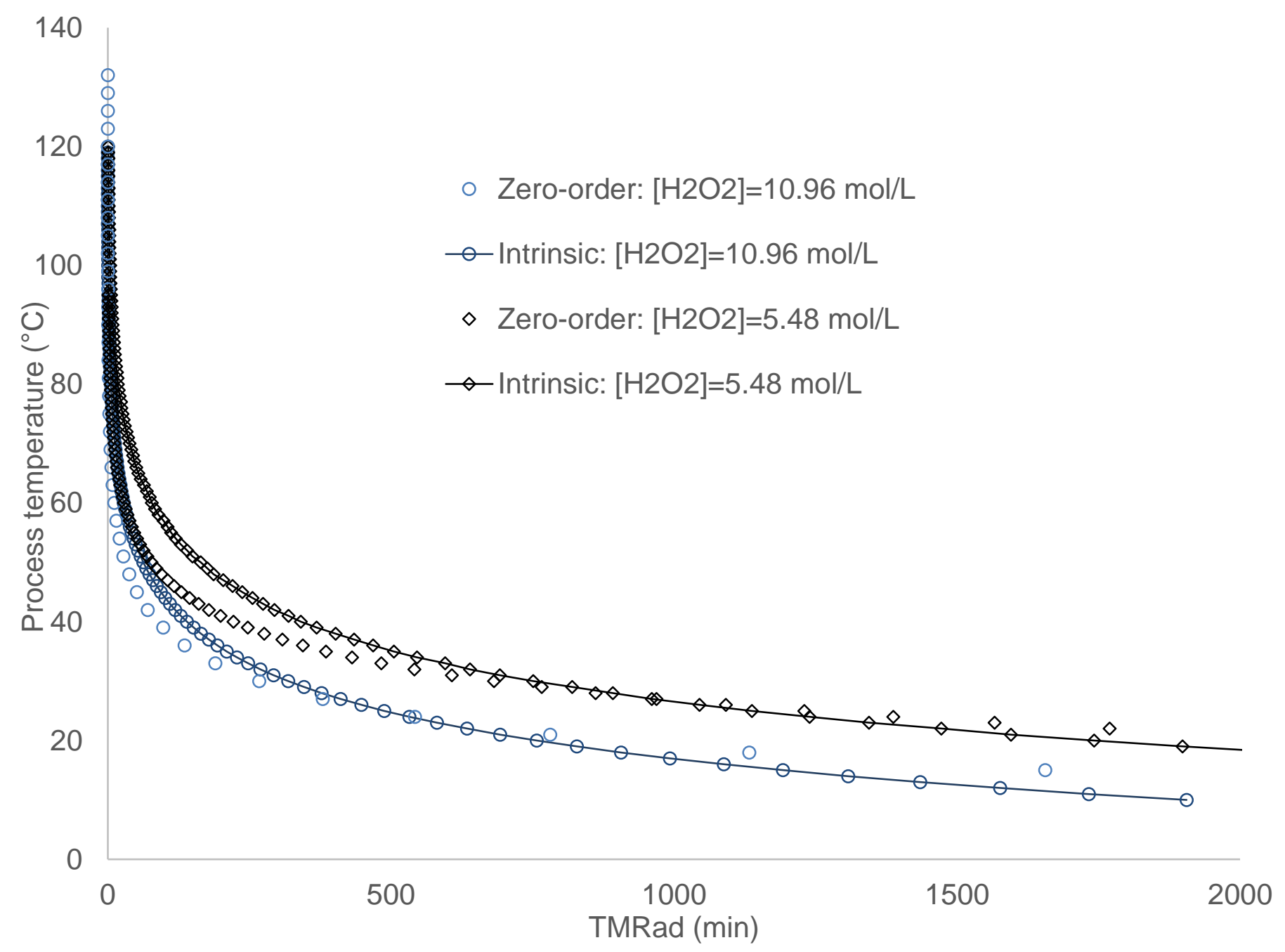

Figure 7. Evolution of $\mathrm{TMR}_{\mathrm{ad}}\left(\mathrm{T}_{\mathrm{P}}\right)$ by using zero-order approximation and intrinsic kinetic model for different hydrogen peroxide concentration. 
Table 3. Influence of hydrogen peroxide concentrations on $\mathrm{T}_{\mathrm{D} 24}$ and $\mathrm{T}_{\mathrm{D} 8}$ by using the zero-order model (experiments illustrated by Figure 4) and the intrinsic kinetic model.

\begin{tabular}{|c|c|c|c|c|c|c|c|c|c|}
\hline \multirow{2}{*}{$\begin{array}{c}\text { Background } \\
\text { heating } \\
\text { rate }\left({ }^{\circ} \mathrm{C} / \mathrm{min}\right)\end{array}$} & \multirow[b]{2}{*}{$\begin{array}{l}{\left[\mathrm{H}_{2} \mathrm{O}_{2}\right]} \\
(\mathrm{mol} / \mathrm{L})\end{array}$} & \multirow[b]{2}{*}{$\begin{array}{l}\text { Tonset } \\
\left({ }^{\circ} \mathrm{C}\right) \\
\end{array}$} & \multirow[b]{2}{*}{$\begin{array}{l}\text { tonset } \\
(\mathrm{min})\end{array}$} & \multicolumn{2}{|c|}{$\begin{array}{l}\text { ZERO- } \\
\text { ORDER }\end{array}$} & \multicolumn{2}{|c|}{$\begin{array}{c}\text { INTRINSIC } \\
\text { KINETIC }\end{array}$} & \multirow[b]{2}{*}{$\begin{array}{l}\text { Difference } \\
\left.\text { TD24 }^{\circ}{ }^{\circ} \mathrm{C}\right)\end{array}$} & \multirow[b]{2}{*}{$\begin{array}{c}\text { Difference } \\
\mathrm{T}_{\mathrm{D} 8}\left({ }^{\circ} \mathrm{C}\right)\end{array}$} \\
\hline & & & & $\begin{array}{l}\mathrm{T}_{\mathrm{D} 24} \\
\left({ }^{\circ} \mathrm{C}\right) \\
\end{array}$ & $\begin{array}{l}\mathrm{T}_{\mathrm{D} 8} \\
\left({ }^{\circ} \mathrm{C}\right) \\
\end{array}$ & $\begin{array}{l}\mathrm{T}_{\mathrm{D} 24} \\
\left({ }^{\circ} \mathrm{C}\right) \\
\end{array}$ & $\begin{array}{l}\mathrm{T} 8 \\
\left({ }^{\circ} \mathrm{C}\right) \\
\end{array}$ & & \\
\hline \multirow{3}{*}{2} & 10.96 & 69.89 & 18.9 & 16.1 & 25.0 & 13 & 26 & -3.1 & 1.0 \\
\hline & 7.3 & 76.29 & 22.25 & 20.8 & 29.8 & 19 & 32 & -1.8 & 2.2 \\
\hline & 5.48 & 81.18 & 25.03 & 23.7 & 33.1 & 24 & 36 & 0.3 & 2.9 \\
\hline
\end{tabular}

One can notice that when the time to reach the $\mathrm{T}_{\text {onset }}\left(\mathrm{t}_{\text {onset }}\right)$ is longer than 90 minutes, then the difference between the safety parameters obtained from the zero-order and the intrinsic kinetic model is more pronounced for this reaction system. When the kinetics of the reaction system is slow, then, the determination of $\mathrm{T}_{\text {onset }}$ is less obvious leading to erroneous safety parameters by using the zero-order approximation.

The good practice is to test different background heating rates to verify the influence on $\mathrm{T}_{\mathrm{D} 24}$ and $\mathrm{T}_{\mathrm{D} 8}$ obtained by using the zero-order approximation. If the values of these safety parameters are very different, more investigation on the kinetics and thermodynamics are needed. 


\section{CONCLUSIONS}

The determination of the $\mathrm{TMR}_{\mathrm{ad}}$ values at different process temperature for the decomposition of hydrogen peroxide in the absence and presence of copper sulfate was investigated. The advanced reactive system screening tool was used to perform experiments under near adiabatic conditions and under mid-pressure to limit the evaporation. By using the zero-order approximation, we have found that the initial pressure of nitrogen does not significantly influence the safety criteria $\mathrm{T}_{\mathrm{D} 24}$ and $\mathrm{T}_{\mathrm{D} 8}$ within the pressure range 27.5-41 bar. However, the values of the background heating rate ( $\beta$ ) significantly influence the different values for these safety criteria for similar experimental conditions.

An intrinsic kinetic model was built to estimate the intrinsic values of $\mathrm{TMR}_{\mathrm{ad}}$ by taking into account the reactant concentrations.

A comparison between zero-order and kinetic model for the determination of the safety parameter, $\mathrm{TMR}_{\mathrm{ad}}, \mathrm{T}_{\mathrm{D} 24}$ and $\mathrm{T}_{\mathrm{D} 8}$, was done. We have noticed that the zero-order approximation does not always overestimate these safety parameters. The difference between the safety criteria obtained from the zero-order approximation and the intrinsic kinetic model vary from -9 to $+21^{\circ} \mathrm{C}$ for this reaction system.

The benefit of ARSST unit is to obtain rapidly the values of $\mathrm{TMR}_{\mathrm{ad}}$ by using the zero-order approximation, but these estimated values are sensitive to the determination of $\mathrm{T}_{\text {onset. }} \mathrm{A}$ good practice with ARSST is to vary the background heating rate $(\beta)$ to verify its influence on $\mathrm{TMR}_{\mathrm{ad}}$ (based on zero-order approximation). 
In that work, decomposition of hydrogen peroxide was used a test system. More investigation should be done by testing different chemical system with different kinetics, to have a general trend regarding the influence of the background heating rate. 


\section{ASSOCIATED CONTENT}

\section{Supporting Information.}

Methodology for the determination of $\mathrm{TMR}_{\mathrm{ad}}$ based on the zero-order assumption; Kinetic model and Modeling results. 


\section{AUTHOR INFORMATION}

\section{Corresponding Author}

Sébastien Leveneur*1,2

${ }^{1}$ Normandie Univ, INSA Rouen, UNIROUEN, LSPC, EA4704, 76000 Rouen, France, E-mail :

sebastien.leveneur@insa-rouen.fr

${ }^{2}$ Laboratory of Industrial Chemistry and Reaction Engineering, Johan Gadolin Process

Chemistry Centre, Åbo Akademi University, Biskopsgatan 8, FI-20500 Åbo/Turku, Finland. 


\section{ACKNOWLEDGMENTS}

The authors express their gratitude to Jean-Pierre Hébert for his technical assistance. The authors thank Morgan Jones, the head of international office of INSA Rouen, to make possible the master thesis of Amine Dakkoune. This paper is dedicated to Professor Tapio Salmi. 


\section{ABBREVIATIONS}

\begin{tabular}{|c|c|}
\hline$\widehat{\mathrm{C}}_{\mathrm{P}_{\text {Cell }}}$ & Specific heat-capacity of the cell $\left[\mathrm{J} \cdot \mathrm{kg}^{-1} \cdot \mathrm{K}^{-1}\right]$ \\
\hline$\widehat{\mathrm{C}}_{\mathrm{pR}}$ & Specific heat-capacity of the reaction mixture $\left[\mathrm{J} \cdot \mathrm{kg}^{-1} \cdot \mathrm{K}^{-1}\right]$ \\
\hline $\mathrm{Ea}$ & Activation energy $\left[\mathrm{J} . \mathrm{mol}^{-1}\right]$ \\
\hline$\Delta \mathrm{H}$ & Reaction enthalpy $\left[\mathrm{J} \cdot \mathrm{mol}^{-1}\right]$ \\
\hline $\mathrm{k}$ & Rate constant \\
\hline $\mathrm{m}_{\text {Cell }}$ & Cell mass $[\mathrm{kg}]$ \\
\hline $\mathrm{m}_{\mathrm{R}}$ & Reaction mixture mass $[\mathrm{kg}]$ \\
\hline qel & Electrical heating-rate $\left[{ }^{\circ} \mathrm{C} \cdot \mathrm{min}^{-1}\right]$ \\
\hline $\mathrm{qr}_{\mathrm{r}}(\mathrm{T})$ & Heat-flow rate due to chemical reactions at temperature $\mathrm{T}\left[\mathrm{J} \cdot \mathrm{s}^{-1}\right]$ \\
\hline $\mathrm{R}$ & Gas constant $\left[\mathrm{J} \cdot \mathrm{mol}^{-1} \cdot \mathrm{K}^{-1}\right]$ \\
\hline $\mathrm{R}^{2}$ & Coefficient of explanation [\%] \\
\hline $\mathrm{R}_{\text {Catalyzed by Cu(II) }}$ & Kinetic rate for the decomposition of hydrogen peroxide by copper (II) $\left[\mathrm{mol} \cdot \mathrm{L}^{-1} \cdot \mathrm{s}^{-1}\right]$ \\
\hline $\mathrm{R}_{\text {decompositon }}$ & Kinetic rate for the decomposition of hydrogen peroxide $\left[\mathrm{mol} \cdot \mathrm{L}^{-1} \cdot \mathrm{s}^{-1}\right]$ \\
\hline $\mathrm{R}_{\text {Spontaneous }}$ & Kinetic rate for the spontaneous decomposition of hydrogen peroxide $\left[\mathrm{mol} \cdot \mathrm{L}^{-1} \cdot \mathrm{s}^{-1}\right]$ \\
\hline $\mathrm{r}_{\mathrm{i}}$ & Rate of formation or disappearance of compound $i\left[\mathrm{~mol} \cdot \mathrm{L}^{-1} \cdot \mathrm{s}^{-1}\right]$ \\
\hline$\Delta \mathrm{T}_{\mathrm{ad}}$ & Adiabatic temperature rise $\left[{ }^{\circ} \mathrm{C}\right]$ \\
\hline $\mathrm{T}_{\mathrm{D} 8}$ & Initial process temperature at which $\mathrm{TMR}_{\mathrm{ad}}$ is 8 hours $\left[{ }^{\circ} \mathrm{C}\right]$ \\
\hline $\mathrm{T}_{\mathrm{D} 24}$ & Initial process temperature at which $\mathrm{TMR}_{\text {ad }}$ is 24 hours $\left[{ }^{\circ} \mathrm{C}\right]$ \\
\hline $\mathrm{T}_{\text {final }}$ & Final temperature under adiabatic conditions $\left[{ }^{\circ} \mathrm{C}\right]$ \\
\hline$t_{\max }$ & Time at $\mathrm{T}_{\max }[\mathrm{min}]$ \\
\hline $\mathrm{T}_{\max }$ & Maximum temperature $\left[{ }^{\circ} \mathrm{C}\right]$ \\
\hline
\end{tabular}




$\begin{array}{ll}\mathrm{T}_{0} & \text { Initial reaction temperature }\left[{ }^{\circ} \mathrm{C}\right] \\ \mathrm{t}_{\text {onset }} & \text { Time at } \mathrm{T}_{\text {onset }}[\mathrm{min}] \\ \mathrm{T}_{\text {onset }} & \text { Onset temperature }\left[{ }^{\circ} \mathrm{C}\right] \\ \mathrm{VP} & \text { Vapor pressure }[\mathrm{bar}] \\ \mathrm{W}_{\mathrm{i}} & \text { Weight percentage of compound } i\end{array}$

Greek letters

$\beta$

$\omega$

$\Phi$

Abbreviations

Background heating rate $\left[{ }^{\circ} \mathrm{C} \cdot \mathrm{min}^{-1}\right]$

Objective function

Thermal inertia factor $\Phi=\frac{m_{R} \bar{C}_{P_{R}}+m_{\text {cell }} \bar{C}_{P_{\text {cell }}}}{m_{R} \bar{C}_{P_{R}}}$
ARSST
Advanced Reactive System Screening Tool
MTSR
Maximum Temperature for Synthesis Reaction [K]
MTT
Maximum Temperature for Technical reasons [K]
$\mathrm{TMR}_{\mathrm{ad}}$
Time to Maximum Rate under Adiabatic conditions [min] 


\section{REFERENCES}

(1) Stoessel, F. Thermal Safety of Chemical Processes; Wiley-VCH Verlag GmbH \& Co. KGaA/ Weinheim, 2008.

(2) Balasubramanian, S. G.; Louvar, J. F. Study of Major Accidents and Lessons Learned. Process Saf. Prog. 2002, 21, 237.

(3) Saada, R.; Patel, D.; Saha, B. Causes and Consequences of Thermal Runaway incidents—Will They Ever Be Avoided? Process Saf. Environ. Prot. 2015, 97, 109.

4) Westerterp, K. R.; Molga, E. J. No More Runaways in Fine Chemical Reactors. Ind. Eng. Chem. Res. 2004, 43, 4585.

(5) Leveneur, S.; Estel, L.; Crua, C. Thermal Risk Assessment of Vegetable Oil Epoxidation. J. Therm. Anal. Calorim. 2015, 122, 795.

(6) Valdes, O. R.; Moreno, V. C.; Waldram, S.; Véchot, L.; Mannan, M. S. Runaway Decomposition of Dicumyl Peroxide by Open Cell Adiabatic Testing at Different Initial Conditions. Process Saf. Environ. Prot. 2016, 102, 251.

(7) Leveneur, S.; Vernieres-Hassimi, L.; Salmi, T. Mass \& Energy Balances Coupling in Chemical Reactors for a Better Understanding of Thermal Safety. Educ. Chem. Eng. 2016, 16, 17.

(8) Valdes, O. J. R.; Moreno, V. C.; Waldram, S. P.; Véchot, L. N.; Mannan, M. S. Experimental Sensitivity Analysis of the Runaway Severity of Dicumyl Peroxide Decomposition Using Adiabatic Calorimetry. Thermochim. Acta 2015, 617, 28.

(9) Leveneur, S.; Salmi, T.; Musakka, N.; Wärnå, J. Kinetic Study of Decomposition of Peroxypropionic Acid in Liquid Phase through Direct Analysis of Decomposition Products in Gas Phase. Chem. Eng. Sci. 2007, 62, 5007.

(10) Leveneur, S. Thermal Safety Assessment through the Concept of Structure-Reactivity: 
Application to Vegetable Oil Valorization. Org. Process Res. Dev. 2017, 21, 543.

(11) Casson, V.; Maschio, G. Screening Analysis for Hazard Assessment of Peroxides Decomposition. Ind. Eng. Chem. Res. 2012, 51, 7526.

(12) Grau, M. D.; Nougués, J. M.; Puigjaner, L. Batch and Semibatch Reactor Performance for an Exothermic Reaction. Chem. Eng. Process. 2000, 39, 141.

(13) Vernieres-Hassimi, L.; Assoudi-Baikari, R. E.; Abdelghani-Idrissi, M.-A.; Mouhab, N. New Analytical Method for Maximum Temperature Assessment in an Exothermic Tubular Chemical Reactor. Chem. Eng. Commun. 2016, 203, 174.

(14) Vernières-Hassimi, L.; Leveneur, S. Alternative Method to Prevent Thermal Runaway in Case of Error on Operating Conditions Continuous Reactor. Process Saf. Environ. Prot. 2015, 98, 365.

(15) Anxionnaz, Z.; Cabassud, M.; Gourdon, C.; Tochon, P. Transposition of an Exothermic Reaction From a Batch Reactor to an Intensified Continuous One. Heat Transfer Eng. 2010, 31, 788.

(16) Noyori, R. Pursuing Practical Elegance in Chemical Synthesis. Chem. Commun. 2005, No. 14, 1807.

(17) Ciriminna, R.; Albanese, L.; Meneguzzo, F.; Pagliaro, M. Hydrogen Peroxide: A Key Chemical for Today's Sustainable Development. ChemSusChem 2016, 9, 3374.

(18) Hage, R.; Lienke, A. Applications of Transition-Metal Catalysts to Textile and Wood-Pulp Bleaching. Angew. Chem., Int. Ed. 2006, 45, 206.

(19) Fauske, H. K. Managing Chemical reactivity—Minimum Best Practice. Process Saf. Prog. 2006, 25, 120.

(20) Kokes, H.; Morcali, M. H.; Acma, E. Dissolution of Copper and Iron from Malachite Ore and 
Precipitation of Copper Sulfate Pentahydrate by Chemical Process. Engineering Science and Technology, an International Journal 2014, 17, 39.

(21) Adebayo, A. O.; Ipinmoroti, K. O.; Ajayi, O. Dissolution Kinetics of Chalcopyrite with Hydrogen Peroxide in Sulphuric Acid Medium. Chem. Biochem. Eng. Q. 2003, 17, 213.

(22) Mlasi, B.; Glasser, D.; Hildebrandt, D. Kinetics of the Decomposition of Hydrogen Peroxide in Acidic Copper Sulfate Solutions. Ind. Eng. Chem. Res. 2015, 54, 5589.

(23) Perez-Benito, J. F. Copper(II)-Catalyzed Decomposition of Hydrogen Peroxide: Catalyst Activation by Halide Ions. Monatsh. Chem. 2001, 132, 1477.

(24) Bhattacharya, A. A General Kinetic Model Framework for the Interpretation of Adiabatic Calorimeter Rate Data. Chem. Eng. J. 2005, 110, 67.

(25) Marco, E.; Cuartielles, S.; Peña, J. A.; Santamaria, J. Simulation of the Decomposition of Di-Cumyl Peroxide in an ARSST Unit. Thermochim. Acta 2000, 362, 49.

(26) Ait Aissa, K.; Zheng, J. L.; Estel, L.; Leveneur, S. Thermal Stability of Epoxidized and Carbonated Vegetable Oils. Org. Process Res. Dev. 2016, 20, 948.

(27) Duh, Y.-S.; Kao, C.-S.; Lee, C.; Yu, S. W. Runaway Hazard Assessment of Cumene Hydroperoxide From the Cumene Oxidation Process. Process Saf. Environ. Prot. 1997, 75, 73.

(28) Huang, C.-C.; Peng, J.-J.; Wu, S.-H.; Hou, H.-Y.; You, M.-L.; Shu, C.-M. Effects of Cumene Hydroperoxide on Phenol and Acetone Manufacturing by DSC and VSP2. J. Therm. Anal. Calorim. 2010, 102, 579.

(29) Véchot, L.; Bigot, J.-P.; Testa, D.; Kazmierczak, M.; Vicot, P. Runaway Reaction of NonTempered Chemical Systems: Development of a Similarity Vent-Sizing Tool at Laboratory Scale. J. Loss Prev. Process Ind. 2008, 21, 359.

(30) Chi, J.-H.; Wu, S.-H.; Shu, C.-M. Thermal Explosion Analysis of Methyl Ethyl Ketone 
Peroxide by Non-Isothermal and Isothermal Calorimetric Applications. $\quad J . \quad$ Hazard. Mater. 2009, $171,1145$.

(31) Veedhi, S.; Sawant, A. Designing a Safer Process for the Reaction of TFA with Sodium Borohydride in THF by Calorimetric Technique. J. Therm. Anal. Calorim. 2013, 111, 1093.

(32) Tang, W.; Sarvestani, M.; Wei, X.; Nummy, L. J.; Patel, N.; Narayanan, B.; Byrne, D.; Lee, H.; Yee, N. K.; Senanayake, C. H. Formation of 2-Trifluoromethylphenyl Grignard Reagent via Magnesium-Halogen Exchange: Process Safety Evaluation and Concentration Effect. Org. Process Res. Dev. 2009, 13, 1426.

(33) Veedhi, S.; Mishra, V.; Kulkarni, S.; Gorthi, R. Incident Investigation on Thermal Instability of an Intermediate Using Adiabatic Calorimeter. J. Therm. Anal. Calorim. 2014, 115, 909.

(34) Shimizu, S.; Imamura, Y.; Ueki, T. Incompatibilities between N-Bromosuccinimide and Solvents. Org. Process Res. Dev. 2014, 18, 354.

(35) Theis, A. E.; Burelbach, J. P.; Askonas, C. F. Safely Scale-up Processes and Accommodate Recipe Changes. Process Saf. Prog. 2009, 28, 135.

(36) Sarge, S. M., Höhne, G. W. H., Hemminger, W. In Calorimetry: Fundamentals, Instrumentation and Applications; Wiley-VCH Verlag GmbH \& Co. KGaA: Weinheim, 2014.

(37) Mannan, M., Lees’ Process Safety Essentials; Butterworth-Heinemann: Oxford, 2014.

(38) Jana, A.K. Process Simulation and Control using Aspen ${ }^{T M}$; PHI Learning: New Delhi, 2012.

(39) Casson, V.; Battaglia, E.; Maschio, G. Hydrogen Peroxide Decomposition Analysis by Screening Calorimetry Technique. Chem. Eng. Trans. 2012, 26, 27.

(40) Koskinen, H.; Leveneur, S.; Sundquist, A.; Musakka, N.; Salmi, T.; Renvall, I. Functionality of Poly(alpha-Hydroxyacrylic Acid) as $\mathrm{H}_{2} \mathrm{O}_{2}$ Stabilising Agent. Oxid. Commun. 2010, 33, 258.

(41) Tatsuoka, T.; Koga, N. Energy Diagram for the Catalytic Decomposition of Hydrogen 
Peroxide. J. Chem. Educ. 2013, 90, 633.

(42) Marzzacco, C. J. The Enthalpy of Decomposition of Hydrogen Peroxide: A General Chemistry Calorimetry Experiment. J. Chem. Educ. 1999, 76, 1517.

(43) Haario, H., 2001. MODEST-User's Guide; ProfmathOy: Helsinki, 2001. 